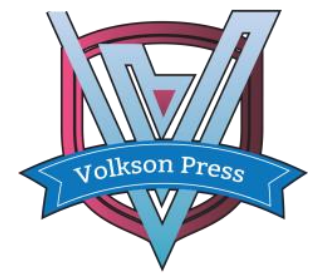

\title{
Research on Application of Employee Benefits Payable under the New Standards
}

\author{
QianqianWu ${ }^{1, *}$, XiupingWang ${ }^{2}$ \\ 1,2,Jiangsu University of Science and Technology, Zhenjiang, China \\ *1757617216@qq.com
}

This is an open access article distributed under the Creative Commons Attribution License, which permits unrestricted use, distribution, and reproduction in any medium, provided the original work is properly cited.

\section{ARTICLE DETAILS}

\section{Article History:}

Received 02 october 2017 Accepted 06 october 2017 Available online 11 october 2017

\section{Keywords:}

Employee benefits; Accounting standard for business enterprise; Financial accounting

\section{ABSTRACT}

Issued by ministry of finance in January 2014, the revised edition of Accounting Standard for Business Enterprise No.9-_Employee Benefits introduced plenty of contents of International Accounting Standards No.19_-Employee Benefits. Compared with the old standards, there exist great changes. Based on the domestic current level of economic development and specific situation of enterprises, to research the impact of these changes on financial statements, financial accounting and the future development, furthermore, to analyze enterprises how to apply the new standards, the innovations and the deficiencies by a case study ,so as to guide the practical operations of enterprises and provide opinions and suggestions.

\section{Introduction}

With the rapid development of China's socialist market economy and the revision of the international accounting standards, the old employee benefits payable accounting standards has been unable to meet the new needs of employee benefits payable accounting and enterprise development. In this situation, Government has promulgated the improved enterprise accounting standard. The new standards have a greater degree of reference to the content of international accounting standards, not only follow the international trend, but also further maintain the international convergence of China's accounting standards [1]. At the same time, based on the specific national conditions of China's economic development, the new standards have revised and improved the old standards, which has been standardizing the order of the market economy. This paper compares employee benefits payable under the new standards with that under the old standards, and deeply study application on employee benefits payable under the new standards. Moreover, on the basis of the study, this paper conducts a case-study which takes SUNING COMMERCE GROUP CO., LTD. as the research object, and further analyzes the impact of new accounting standards for enterprises, and demonstrates practical application in the enterprise under the new accounting standards.

\section{Differences between the old and new accounting standards}

\subsection{Differences in definition of employee benefits}

Employee benefits refers to all forms of consideration or compensation given by an enterprise in exchange for service rendered by employees or for the termination of employment relationship. The new accounting standards expands the contents of employee benefits, which is that for its employees, what enterprise needs to pay include not only in-service salary but also post-employment benefits and associated long-term benefits. At a word, new employee benefit includes short-term employment benefits, termination benefits and other long-term employee benefits, which replaces the old one consisting of wages, and five social insurance and one housing fund ${ }^{[2]}$.

\subsection{Differences in definition of employee}

Employees in new standard include all personnel who have entered into an employment contract with the enterprise, including full-time, part-time and temporary employees. In addition, employees also include those personnel who, although no employment contracts have been entered into with the enterprise, are formally appointed by the enterprise ${ }^{[3]}$. The new accounting standards expand the scope of employees to make it be more in line with the actual needs of the market. The new standards redefines scope of employees which introduces dispatched labor, and stipulates fulltime, part-time and temporary employees' benefits, so that make it more applicable.

\subsection{Differences in accounting processing}

Accounting processing refers to the process of accounting for employee benefits ${ }^{[4]}$. Compared to the original standards, the new standards has two differences in accounting process: (1) accounting method has been unified. In-service time has been taken as accounting calculation time, short-term employee benefits has been defined, and employee benefits have been adopted only by fair value measurement. (2) Measurement and confirmation of post-employment benefits have been defined, which consists of defined contribution plans and defined benefit plan. Defined contribution plan refers to that enterprise pay a fixed amount to the independent fund, without further payment obligations. Defined benefit plan refers to that enterprise pay the amount which guarantees payment obligation of future pension could be carried out smoothly at least to independent fund, with the obligation of further payment at the same time.

3. Application of Employee Benefits Payable under the new standards

\subsection{Paid absences}

The new standards introduce a measurement of paid absences which is an important complement to short-term employee benefits. Paid absences here refers to cumulative paid absences, and short-term paid absences could be divided into cumulative paid absences and non-cumulative paid absences. For the non-cumulative paid absences, only actual employee absenteeism occurs, enterprise could be able to confirm the relevant employee benefits ${ }^{[5]}$. For cumulative paid absences, the rights could be carried over to the next accounting period, such as annual leave and so on. When the employee fail to exercise the right of paid absences, enterprises should be expected to pay amount of cumulative paid absences and confirm the relevant employee benefits. Compensation should be deducted from the accrued liabilities which was calculated before while using cash.

\section{2 post-employment benefits}


Post-employment benefits has been added to employee benefits payable as a new content under the new standards, however, the related accounting and accounting treatment is relatively complicated, so that the enterprises should deeply study the content of the new standards before application. Under the new standards, pension insurance and unemployment insurance of employee benefits payable would be included in the employee benefits payable - post-employment benefits subject, which is different from the old standards under which that was included employee benefits payable - social insurance subject. In addition, if the enterprise fails to pay off account payable in the next year after the end of annual report, account payable should be included in employee benefits payable subject to be accounted after discounting with the discount rate of new standards [6]. However, annuity of defined contribution plan involves actuarial assumption, which requires the actuary to assist in the financial accounting.

\subsection{Termination benefits}

Termination benefits are compensation provided when an enterprise decides to terminate the employment relationship with employees before the end of the employment contracts. If the enterprise is able to pay off account payable in the next year after the end of annual report, the account payable applies short-term employee benefits accounting treatment, and should be included in the employee benefits payable - termination benefits. However, if the enterprise fails to pay off, the accounting treatment should be carried out in accordance with other long-term employee benefits of the new standards [7].

\section{Case study - the impact of new accounting standards on Enterprises}

This paper analyzes the financial statements issued by SUNING COMMERCE GROUP CO., LTD after the promulgation of the new standards, with a view to explore the impact of the new accounting standards on enterprises. SUNING COMMERCE is a listed company mainly engaged in the retail of electrical appliances (002024). This paper takes the SUNING COMMERCE as an example to illustrate the specific impact of the new standards on corporate financial statements.

Table 1, table 2 and table 3 are employee benefits payable and defined contribution plan from consolidated financial statements of SUNING COMMERCE in 2014. Table 4 is employee benefits payable in 2013. Due to the promulgation of the new standards in 2014, the original defined contribution plans has been separate from employee benefits payable, which has been changed from 290.36 million yuan to 289.74 million yuan. SUNING COMMERCE adjusted defined contribution plans amounted to 625 thousand yuan in 2013, so that the newly introduced post-employment benefits reclassifies employee benefits payable, which makes employee benefits accounting more accurate.

Table 1. Employee benefits payable from consolidated financial statements of SUNING COMMERCE in $2014{ }^{[8]}$ (Ten thousand yuan)

\begin{tabular}{lcc}
\hline Date & December 31st, 2014 & December 31st, 2013 \\
\hline Employee Benefits Payable & 34799.6 & 28973.6 \\
Defined Contribution Plan Payalbe & 556.7 & 62.5 \\
Total & 35356.3 & 29036.1 \\
\hline
\end{tabular}

Table 2. Short-term employee benefits from consolidated financial statements of SUNING COMMERCE in $2014^{[8]}$ (Ten thousand yuan)

\begin{tabular}{|c|c|c|c|c|}
\hline & $\begin{array}{c}\text { End of } \\
2013 \\
\end{array}$ & Increment & Decrement & $\begin{array}{c}\text { End of } \\
2014 \\
\end{array}$ \\
\hline Wages, bonuses, allowances and subsidies & $\begin{array}{c}23154 . \\
4\end{array}$ & 464048.1 & -459128.7 & $\begin{array}{c}28073 \\
8\end{array}$ \\
\hline Welfare & 4450.2 & 17690.7 & -17159.1 & 4981.8 \\
\hline Social insurance & 47.5 & 40980.5 & -40743.7 & 284.3 \\
\hline Including: Health insurance & 40.3 & 32196.5 & -31989.6 & 247.2 \\
\hline Injury insurance & 2.7 & 3455.4 & -3443.9 & 14.2 \\
\hline Maternity insurance & 4.5 & 5328.6 & -5310.2 & 22.9 \\
\hline Housing accumulation fund & 53.6 & 24985.2 & -24690.3 & 348.5 \\
\hline $\begin{array}{l}\text { Labor } \\
\text { union expenditure and employee education expen } \\
\text { ses }\end{array}$ & 1267.9 & 3375.6 & -3532.3 & 1111.2 \\
\hline Total & $\begin{array}{c}28973 . \\
6\end{array}$ & 551080.1 & -545254.1 & $\begin{array}{c}34799 \\
6\end{array}$ \\
\hline
\end{tabular}

Table 3. Defined Contribution Plan from consolidated financial statements of SUNING COMMERCE in 2014 ${ }^{[8]}$ (Ten thousand yuan)

\begin{tabular}{lcccc}
\hline & $\begin{array}{c}\text { End of } \\
\mathbf{2 0 1 3}\end{array}$ & Increment & Decrement & $\begin{array}{c}\text { End of } \\
\mathbf{2 0 1 4}\end{array}$ \\
\hline Basic endowment insurance & 53.1 & 44214.6 & -43754.5 & 512.8 \\
Uncmployment endowment insurance & 9.4 & 7366.1 & -7331.6 & 43.9 \\
Total & 62.5 & 51580.7 & -51086.5 & 556.7 \\
\hline
\end{tabular}

Table 4. Note of Employee benefits payable report of SUNING COMMERCE in $2013^{[8]}$ (Ten thousand yuan)

\begin{tabular}{|c|c|c|c|c|c|}
\hline \multirow{2}{*}{\multicolumn{2}{|c|}{ Wages, bonuses, allowances and subsidies }} & $\begin{array}{l}\text { End of } \\
2012\end{array}$ & Increment & Decrement & $\begin{array}{l}\text { End of } \\
2013\end{array}$ \\
\hline & & $\begin{array}{c}21232 . \\
4\end{array}$ & 384606.1 & -382684.1 & $\begin{array}{c}23155 . \\
4\end{array}$ \\
\hline Welfare & & 3334.2 & 16241.6 & -15125.6 & 4450.2 \\
\hline $\begin{array}{l}\text { Table } 4 \text { con. } \\
\text { Social insur }\end{array}$ & rance & 60.3 & 80091.4 & -80041.7 & 110 \\
\hline Including: & Health insurance & 22.1 & 29363.4 & -29345.2 & 40.3 \\
\hline & Basic endowment & 29.1 & 0.8 & 76.8 & 53.1 \\
\hline & Une & 5.1 & & & 9.4 \\
\hline & Injury & 1.5 & 1909.4 & -1908.2 & 2.7 \\
\hline & Mate & 2.5 & & & 4.5 \\
\hline Housing acc & cumulation fund & & 20635 & -20581.4 & 53.6 \\
\hline $\begin{array}{l}\text { Labor } \\
\text { union expen }\end{array}$ & nditure and employee education expenses & 1256.9 & 2133.7 & -2122.7 & 1267.9 \\
\hline Total & & $\begin{array}{l}25883 . \\
8\end{array}$ & 503707.8 & -500555.5 & $\begin{array}{cc}5 & 29036 . \\
& 1\end{array}$ \\
\hline
\end{tabular}

Table 5.Comparison of employee benefits project in 2013 and in 2014 from the consolidated balance sheet of SUNING COMMERCE [9]

\begin{tabular}{llll}
\hline subject & $\mathbf{2 0 1 3}$ & $\mathbf{2 0 1 4}$ & $\mathbf{2 0 1 5}$ \\
\hline $\begin{array}{l}\text { long-term employee benefits } \\
\text { payable }\end{array}$ & None & New & Yes \\
Employee benefits payable & Yes & Yes & Yes \\
\hline
\end{tabular}

Table 5 shows that after the promulgation of the new standards, long-term employee benefits payable project has been added to non-current liability of enterprise balance sheet, which is pension amount of post-employment benefits. It was incorporated into the employee benefits payable subject to carry out accounting under the old standards, but under the new standards it would be incorporated into the long-term employee benefits payable as one of non-current liabilities to be measured. The differences referring to accounting treatment would have an impact on list and disclosure of the financial statements.

\section{Conclusions}

In order to maintain the international convergence of China's accounting standards, adapt to changes in the new situation and improve the old standards, the Ministry of Finance issued the new standards. Compared with the original standards, the new accounting standards further expand the scope of employee benefits, employee and so on, which means that regulation and supervision of accounting becomes more and more strict. Furthermore, due to the revision of accounting treatment methods, for enterprises, employee benefits accounting has been calculated according to the related benefit objects under the new standards. Employee benefits of research personnel has been granted to be treated by capitalization, which balances the expenditure of employee benefits of research personnel and corporate profits. Finally, the new standards puts forward higher requirements on comprehensive quality of accountant, so that the accountant should deeply study the new standard to perform better in accounting treatment according to it.

However, the new standards still exist some deficiencies such as unreasonable classification of employee benefits, existence of subjectivity in specific benefits measurement in the aspect of theory, and imperfect accounting treatment for the non-monetary welfare, insufficiently specific stipulation of relevant provisions in the aspect of practice, which affect the enterprise's confirmation and measurement.

In short, the promulgation of the new accounting standards make it more in line with international practice, for most companies, which is more good than harm and help domestic enterprises to promote their competitiveness in the international market. In the aspect of employee benefits payable, it could solve some problems encountered in practice, moreover, provide a solid safeguard for the development of domestic enterprises and the interests of the employee.

\section{References}

[1] Fang Wang. Thoughts on accounting standards before and after modification of employee benefits. Economic Research Guide, 2014(24):126-127. 
[2] Wenqi Zhu. Thoughts on changes of employee benefits standards in new accounting standards for enterprises in 2014. Money China, 2015(4):210-211.

[3] Fanglan Xu, Hong Ren. Discussion on financial accounting for postemployment benefits under new accounting standards. Chinese \& Foreign Entrepreneurs, 2015(32):25.

[4] Yu Guo, Hongbo Li, Jingxuan Jia. A comparative study of new and old accounting standards for employee benefits. China Market, 2014(49):6970.
[5] Nana Wu. Discussion on impact on financial accounting for employee benefits under new accounting standards. Market Modernization, 2017(4):212-213.

[6] Danhua Zhen. Accounting treatment on employee benefits and nonmonetary benefits under new standards. Commercial Times, 2017(6):115116.

[7] Hongbai Li. Discussion on financial accounting in the revised employee benefits standards. Accounting Learning, 2016(13):118-118.

[8] 2014 Annual Report of SUNING COMMERCE GROUP CO., LTD.

[9] 2013 Annual Report of SUNING COMMERCE GROUP CO., LTD. 